\title{
Hormone Imbalance
}

National Cancer Institute

\section{Source}

National Cancer Institute. Hormone Imbalance. NCI Thesaurus. Code C92809.

An abnormal finding indicating that the level of a particular hormone is not within the expected normal values. 